\title{
SLAUGHTER RESULTS ANALYSIS OF GRASS-FED BEEF CATTLE
}

\author{
Inga Muižniece, Daina Kairiša \\ Latvia University of Agriculture \\ muiznieceinga@inbox.lv
}

\begin{abstract}
Cattle fattening, first of all, should be beneficial for a farmer, therefore, in Latvia more suitable are such average intense fattening methods as fattening with grass fodder. In the world, demand for beef, produced in an environmentally friendly manner, ensuring the appropriate animal welfare conditions, is growing. The aim of the study was to find out the fattening results of Hereford (HE) and Aberdinanguss (AB) pure-bred bulls and their crosses when fed with grass fodder. The study was conducted in 2015 and 2016 within the framework of the project 'Baltic Grassland Beef'. AB crossbreed bulls were slaughtered when they were $519 \pm 16.6$ days old, but HE pure-bred bulls $-584 \pm 7.3$ days old $(\mathrm{p} \leq 0.05)$. The biggest live weight and slaughter weight showed HE crossbreed group bulls $-557 \pm 19.4 \mathrm{~kg}$ and 293 $\pm 12.2 \mathrm{~kg}$, respectively, but the biggest live weight daily gain from birth to slaughter was observed to AB pure-bred group bulls $-952 \pm 24$.7. Carcass conformation score in muscle development was the highest for AB pure-bred group bulls. Their average conformation score was $3.2 \pm 0.08$ points. In terms of fat score development, carcass with the best quality was obtained from HE crossbreed group bulls, the resulting fat score $-2.4 \pm 0.10$. The obtained results prove that pure-bred and crossbreed bulls used in this research are suitable for fattening with grass in the conditions of Latvia.
\end{abstract}

Key words: beef cattle fattening, grass fattening, bulls, carcass characteristics, growth.

\section{Introduction}

In recent years in Latvia, the number of beef cattle herd has increased as agro-climatic and ecological conditions are suitable for development of this sector. It is a great opportunity for farmers to manage their grassland and also gain some profit. Beef cattle farms are mostly organic and according to scientists, products grown in these areas are especially useful for human health (Lujane, Oshmane, \& Jansons, 2013).

Carcass and meat quality are influenced by many factors, which can be divided into two groups: endogenous factors (directly related to the animal, such as breed, age, gender, etc.) and exogenous factors (food, weather conditions, slaughter process, etc.). These factors are combined in environmental factors group. From this group, feeding has a big role in high quality product sourcing (Dannenberger et al., 2006).

Considering the current economic situation in Latvia, cattle fattening should be inexpensive and profitable to the farmer. In this case, intensive feeding techniques, where mostly grain feed or concentrates are used, would not be suitable. In the world more popular has become grass-fed beef, where for cattle fattening mainly is used grass forage, but grain feeding is used only if necessary. This type of fattening is also closely related to the topical issue of preventing the direct competition between animals and humans for food products (feed no food) and reduction of environmental problems (Chassot, 2008).

Grass forage in Latvian weather conditions is the cheapest feeding material for summer period, but its economic efficiency depends on the grass yield and quality - the more economical is the feed obtained, the higher they are. Grassland productivity level and quality of the harvest can be meaningfully regulated, as they depend on the sward botanical composition and density. Grass dry matter contains all the necessary nutrients for animals, which allows us to get delicious and biologically wholesome meat, but at the same time ensures quality and quantity rising of meat. (Lujane, Oshmane, \& Jansons, 2013).

So far in Latvia there have been separate studies of beef cattle fattening, however, there is a lack of research on the most appropriate choice of breeds of young animals for fattening with grass forage. Many foreign scientists (Hollo et al., 2012; Jukna et al., 2017; Pesonen, Honkavaar, \& Huuskonen, 2013) have researched the growth of beef cattle breeds, fattening and carcass quality characteristics, but in general, these studies have been conducted on the intensive fattening conditions. The aim of this study was to explain the fattening results of $\mathrm{HE}$ and $\mathrm{AB}$ pure-bred bulls and their crosses (from father side $\mathrm{HE}$ and $\mathrm{AB}$ sires) using grass forage.

\section{Materials and Methods}

The study was conducted in 2015 and 2016 within the framework of the project 'Baltic Grassland Beef'. For fattening, bulls were fed with grass forage, in the winter with silage and hay, but in the summer pasture grass, silage and hay.

In this research, 89 pure--bred and crossbreed bulls from different Latvian farms were used. Bulls were slaughtered in a sertified slauhgterhouse 'Agaras' (Lithuania).

Four study groups were created for data analysis:

1. Aberdinanguss pure-bred bulls $(\mathrm{AB})-24$ bulls;

2. Hereford pure-bred bulls (HE) - 25 bulls;

3. Aberdinanguss crossbreed group bulls (AB crosbreed) - 16 bulls; 
4. Hereford crossbreed group bulls (HE crosbreed) -24 bulls.

$\mathrm{AB}$ crossbreed and HE crossbreed study groups were created from bulls whose fathers were $A B$ and HE pure-bred sires, but from mother's side there were different beef breed and crossbreed cows.

Data on bulls belonging to the breed, date of birth, birth weight were obtained from the Latvian Agricultural Data Centre database, but the slaughter data - carcass weight, conformation and fat score from the slaughterhouse 'Agaras'.

Using the growth rates of the bulls, the average daily weight gain in grams was calculated by the following formula (1):

$$
a=\frac{W t-W 0}{t} \times 1000
$$

where $\mathrm{Wt}-$ live weight before slaughter, $\mathrm{kg}$ W0 - birth weight, $\mathrm{kg}$ $\mathrm{t}$ - age before slaughter, in days

Obtained from slaughter data, dressing percentage $\%$ was calculated according to the following (2):

$$
K=\frac{W k}{W t} \times 100
$$

where $\mathrm{Wk}$ - slaughter weight, $\mathrm{kg}$ $\mathrm{Wt}$ - live weight before slaughter, $\mathrm{kg}$

After slaughtering of the bulls, their carcass weighing and muscle development evaluation was done according to the SEUROP classification. Beef carcasses for conformation are graded according to the EUROP scale: E - excellent (numerical designation - 1) $\mathrm{U}$ - very good (2), $\mathrm{R}$ - right (3), $\mathrm{M}$ - medium (4), P - poor (5) muscle development. Fat score was based on visual evaluation of carcasses in the range from 1 to 5 , where 1 - very low, 2 - low, 3 - moderate, 4 - very good 5 - very high.

Analysis of the data acquired was based on the indicators of descriptive statistics: arithmetical mean, standard error and coefficient of variation. T-test for average values was used for significance determination. Different letters $(a, b, c)$ on tables mark significant differences at $p \leq 0.05$. For trait relationship, correlation analysis was performed, which was established between the slaughter traits for all research group animals together (in total 89).

\section{Results and Discussion}

The average slaughter age of bulls from the study groups ranged from 519 to 584 days (Table 1). HE pure-bred group bulls were slaughtered as the oldest, the average age was $584 \pm 7.3$ days, which was significantly higher than for the rest of the group bulls - the difference between $\mathrm{AB}$ pure-bred group bulls was 48 days, with $\mathrm{AB}$ crossbreed group bulls 65 days, but with HE crossbreed group bulls for 22 days $(\mathrm{p} \leq 0.05)$. The AB crossbreed group bulls were slaughtered youngest. The average age at slaughtering was $519 \pm 16.6$ days, which is significantly different from $\mathrm{HE}$ pure-bred and $\mathrm{HE}$ crossbreed bull results $(p \leq 0.05)$. Between $A B$ pure-bred and AB crossbreed group bulls there are not significant differences between the average age before slaughter. In Pesonen, Honkavaar, \& Huuskonen, (2012, 2013) research,

\section{Bulls slaughter results}

Table 1

\begin{tabular}{|l|c|c|c|c|c|c|c|c|}
\hline \multirow{2}{*}{\multicolumn{1}{|c|}{ Indicators }} & \multicolumn{9}{c|}{ Pure-bred or crossbreed } \\
\cline { 2 - 9 } & \multicolumn{2}{|c|}{$\begin{array}{c}\mathrm{AB} \\
(\mathrm{n}=24)\end{array}$} & \multicolumn{2}{c|}{$\begin{array}{c}\mathrm{HE} \\
(\mathrm{n}=25)\end{array}$} & $\begin{array}{c}\text { AB crosbreed } \\
(\mathrm{n}=16)\end{array}$ & \multicolumn{2}{c|}{$\begin{array}{c}\text { HE crosbreed } \\
(\mathrm{n}=24)\end{array}$} \\
\cline { 2 - 9 } & $\mathrm{x} \pm \mathrm{Sx}$ & $\mathrm{V}, \%$ & $\mathrm{x} \pm \mathrm{Sx}$ & $\mathrm{V}, \%$ & $\mathrm{x} \pm \mathrm{Sx}$ & $\mathrm{V}, \%$ & $\mathrm{x} \pm \mathrm{Sx}$ & $\begin{array}{c}\mathrm{V}, \\
\%\end{array}$ \\
\hline Age before slaughter, days & $\begin{array}{c}536 \\
\pm 0.9^{\mathrm{a}}\end{array}$ & 12.0 & $\begin{array}{c}584 \\
\pm 7.3^{\mathrm{b}}\end{array}$ & 6.2 & $\begin{array}{c}519 \\
\pm 16.6^{\mathrm{a}}\end{array}$ & 12.8 & $\begin{array}{c}562 \\
\pm 9.4^{\mathrm{c}}\end{array}$ & 8.2 \\
\hline Live weight before slaughter, kg & $\begin{array}{c}546 \\
\pm 13.7^{\mathrm{a}}\end{array}$ & 12.3 & $\begin{array}{c}524 \\
\pm 8.7^{\mathrm{a}}\end{array}$ & 8.3 & $\begin{array}{c}525 \\
\pm 22.2^{\mathrm{a}}\end{array}$ & 16.9 & $\begin{array}{c}557 \\
\pm 19.4^{\mathrm{a}}\end{array}$ & 17.0 \\
\hline $\begin{array}{l}\text { Daily weight gain from birth to } \\
\text { slaughter per day, g }\end{array}$ & $\begin{array}{c}952 \\
\pm 24.7^{\mathrm{a}}\end{array}$ & 12.7 & $\begin{array}{c}822 \\
\pm 14.6^{\mathrm{b}}\end{array}$ & 8.9 & $\begin{array}{c}941 \\
\pm 40.7^{\mathrm{a}}\end{array}$ & 17.3 & $\begin{array}{c}929 \\
\pm 36.0^{\mathrm{a}}\end{array}$ & 19.0 \\
\hline Slaughter weight, kg & $\begin{array}{c}280 \\
\pm 8.0^{\mathrm{ab}}\end{array}$ & 14.0 & $\begin{array}{c}266 \\
\pm 4.3^{\mathrm{a}}\end{array}$ & 8.1 & $\begin{array}{c}277 \\
\pm 11.6^{\mathrm{ab}}\end{array}$ & 16.8 & $\begin{array}{c}293 \\
\pm 12.2^{\mathrm{b}}\end{array}$ & 20.4 \\
\hline Dressing percentage, \% & $\begin{array}{c}51.3 \\
\pm 0.39^{\mathrm{a}}\end{array}$ & 3.7 & $\begin{array}{c}50.9 \\
\pm 0.40^{\mathrm{a}}\end{array}$ & 3.9 & $\begin{array}{c}52.8 \\
\pm 0.49^{\mathrm{b}}\end{array}$ & 3.7 & $\begin{array}{c}52.4 \\
\pm 0.46^{\mathrm{b}}\end{array}$ & 4.3 \\
\hline
\end{tabular}

$\mathrm{a} b \mathrm{c}-$ significant differences between the study groups, $\mathrm{p} \leq 0.05$. 
similarly to our study, it was observed that AB purebred bulls were slaughtered earlier as HE pure-bred bulls. AB pure-bred bulls were slaughtered at the age of 526 days, with the difference to our study of 10 days, but HE pure--bred bulls 561 days old - the difference to our study of 23 days. In our study, the age before the slaughter was higher, which can be explained by the fact that fattening was carried out only with forage, therefore the animals were growing slower.

The average live weight of bulls before slaughter ranged from $524 \mathrm{~kg}$ to $557 \mathrm{~kg}$. HE crossbreed bulls showed higher live weight before slaughter $-557 \pm$ $19.4 \mathrm{~kg}$, while HE pure-bred bulls were slaughtered at the lowest live weight $-524 \pm 8.7 \mathrm{~kg}$, however, significant differences between the groups did not exist.

The average daily weight gain from birth to slaughter in the study groups ranged from $822 \mathrm{~g}$ to $952 \mathrm{~g}$. The biggest daily weight gain was observed for AB pure-bred bull group - $952 \pm 24.7 \mathrm{~g}$, which was over $130 \mathrm{~g}$ higher than for HE purebred bull group $(\mathrm{p} \leq 0.05)$. The differences in daily weight gain from birth to slaughter per day between AB crossbreed and HE crossbreed bulls were not significant.

The biggest slaughter weight was obtained from HE crossbreed group bulls $-293 \pm 12.2 \mathrm{~kg}$, which was about $13 \mathrm{~kg}$ more than from AB pure-bred bulls $(280 \pm 8.0 \mathrm{~kg}), 27 \mathrm{~kg}$ more than HE pure-bred bulls $(266 \pm 4.3 \mathrm{~kg})$ and about $16 \mathrm{~kg}$ more than from the AB crossbreed group bulls $(277 \pm 11.6 \mathrm{~kg})$. Significantly different slaughter weight results were between HE pure-bred and HE crossbreed group bulls ( $\mathrm{p} \leq 0.05)$; among other groups significant differences were not identified. The Latvian study (Muizniece \& Kairisa, 2016) proves that in organic farming conditions HE pure-bred bulls get carcass weight $298 \mathrm{~kg}$ before slaughter at the bull age of 615 days.

The biggest dressing percentage was showed by AB crossbreed group bulls $-52.8 \pm 0.49 \%$, while the lowest - by HE pure-bred bulls $-50.9 \pm 0.40 \%$; the difference is significant $(\mathrm{p} \leq 0.05)$.

$\mathrm{AB}$ crossbreed group bull dressing percentage is also significantly higher than $\mathrm{AB}$ pure-bred bull dressing percentage $-51.3 \pm 0.39 \%(\mathrm{p} \leq 0.05)$. HE crossbreed group bull dressing percentage $-52.4 \pm$ $0.46 \%$ - is higher than $\mathrm{AB}$ and HE pure-bred group bull dressing percentage result $(\mathrm{p} \leq 0.05)$. There are no significant differences between $\mathrm{AB}$ and $\mathrm{HE}$ crossbreed group bull dressing percentage indicators. Using different fattening technologies, a number of researchers found out that the average AB purebred bull dressing percentage ranged from 55.2\% - 59.3\%, while for HE pure-bred bulls from 54.1\% - 56.0\%. (Barton et al., 2006; Pesonen, Honkavaar, \& Huuskonen, 2012; Pesonen, Honkavaar, \& Huuskonen, 2013; Chassot, 2015).

Evaluation of the development of the carcass conformation score ranged from 3.2 to 3.5 points. The best score was obtained from AB pure-bred bull group $-3.2 \pm 0.08$ points (Table 2). From this group $79 \%$ of carcasses were evaluated as R class, but $21 \%$ of carcasses as $\mathrm{O}$ class. The lowest score for the carcass was received by HE pure-bred bulls and HE crossbreed group bulls $-3.5 \pm 0.10$ points, which is significantly lower rating than from $\mathrm{AB}$ pure-bred bulls ( $\mathrm{p} \leq 0.05$ ). In HE pure--bred bull group $52 \%$ of carcasses were assessed as in the R class, but $48 \%$ in $\mathrm{O}$ class. By contrast, from HE crossbreed bull group $54 \%$ of carcasses corresponded to the $\mathrm{R}$ class, but $46 \%$ of carcasses - to O class.

Carcasses from all group bulls were evaluated as 2nd and 3rd fat class. In all study groups there were no carcasses which were evaluated as belonging to the 1 st, 4 th or 5 th fat class.

Several foreign scientific studies have shown that $\mathrm{AB}$ pure-bred cattle carcass fat score is much higher than for late maturity breeds (Chambaz et al., 2003; Barton et al., 2006; Alberti et al., 2008; Pesonen, Honkavaar, \& Huuskonen, 2012), which is also consistent with our study - AB pure-bred bull fat score was $2.2 \pm 0.08$ points, but HE pure-bred group bull fat score was only $2.1 \pm 0.06$ points. According to the classification of meat breeds of cattle after their maturation rate, $\mathrm{AB}$ pure-bred bulls belong to the early maturity breeds, but HE pure-bred bulls to medium late maturity breeds (Philips, 2010).

Table 2

Quality of bull carcasses

\begin{tabular}{|l|c|c|c|c|c|c|c|c|}
\hline \multirow{2}{*}{\multicolumn{1}{|c|}{ Indicators }} & \multicolumn{7}{|c|}{ Purebred or crossbreed } \\
\cline { 2 - 9 } & \multicolumn{2}{|c|}{$\begin{array}{c}\mathrm{AB} \\
(\mathrm{n}=24)\end{array}$} & \multicolumn{2}{c|}{$\begin{array}{c}\text { HE } \\
(\mathrm{n}=25)\end{array}$} & \multicolumn{2}{c|}{$\begin{array}{c}\text { AB crossbreed } \\
(\mathrm{n}=16)\end{array}$} & \multicolumn{2}{c|}{$\begin{array}{c}\text { HE crossbreed } \\
(\mathrm{n}=24)\end{array}$} \\
\cline { 2 - 9 } & $\mathrm{x} \pm \mathrm{Sx}$ & $\mathrm{V}, \%$ & $\mathrm{x} \pm \mathrm{Sx}$ & $\mathrm{V}, \%$ & $\mathrm{x} \pm \mathrm{Sx}$ & $\mathrm{V}, \%$ & $\mathrm{x} \pm \mathrm{Sx}$ & $\mathrm{V}, \%$ \\
\hline Conformation score, points & $\begin{array}{c}3.2 \\
\pm 0.08^{\mathrm{a}}\end{array}$ & 12.9 & $\begin{array}{c}3.5 \\
\pm 0.10^{\mathrm{b}}\end{array}$ & 14.7 & $\begin{array}{c}3.4 \\
\pm 0.13^{\mathrm{ab}}\end{array}$ & 14.8 & $\begin{array}{c}3.5 \\
\pm 0.10^{\mathrm{b}}\end{array}$ & 14.7 \\
\hline Fat score, points & $\begin{array}{c}2.2 \\
\pm 0.08^{\mathrm{a}}\end{array}$ & 17.6 & $\begin{array}{c}2.1 \\
\pm 0.06^{\mathrm{a}}\end{array}$ & 13.3 & $\begin{array}{c}2.2 \\
\pm 0.10^{\mathrm{ab}}\end{array}$ & 18.4 & $\begin{array}{c}2.4 \\
\pm 0.10^{\mathrm{b}}\end{array}$ & 20.8 \\
\hline
\end{tabular}

$\mathrm{a} b$ - significant differences between the study groups, $\mathrm{p} \leq 0.05$. 


\section{Bull fattening and slaughter trait phenotypic correlation}

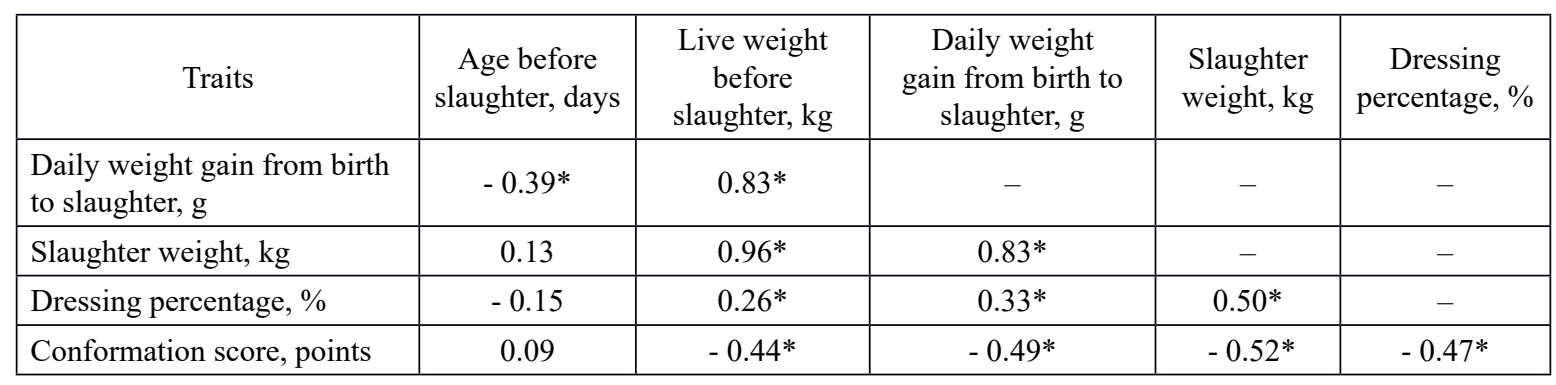

$* \mathrm{p}<0.05$.

Among all study groups, HE crossbreed group bulls showed the highest fat score $-2.4 \pm 0.10$ points, which can be explained by the crossing result of the positive heterosis effect. The fat score of the HE crossbreed bull carcasses is significantly different from the fat score of the $\mathrm{AB}$ and $\mathrm{HE}$ groups pure-bred bulls $(\mathrm{p} \leq 0.05)$.

As shown in Huuskonen et al. (2009) study, which was carried out in Finland, by incorporating in the feed ration grain feed for HE pure-bred bulls, it is possible to gain carcass fat score up to 4.4-4.5. points, regardless of the keeping conditions. These indicators already are approaching the 5th fat class, which is considered undesirable because such carcasses are with too much fat. As Chassot (2008) concludes, if in fattening are used excessive amounts of grain feed or concentrates for such medium intense breed as $\mathrm{AB}$, then it can lead to too fatty carcass.

According to our study, if for fattening is used grass, it is possible to get carcasses with enough fat level. Including grain in feed ration for pure-bred and crossbreed bulls would cause too big fat level formation, which might have a negative impact on the carcass quality. It would be necessary to feed grains only at the end of fattening, if the fat level is not developed enough.

To find out the relationship between the fattening and slaughter traits, correlation analysis was performed (Table 3). The results show that between the live weight before slaughter and daily weight gain from birth to slaughter, and the live weight before slaughter and slaughter weight there is a strong positive correlation - 0.83 and 0.96 , respectively. Between the daily weight gain from birth to slaughter and slaughter weight, there also is a strong positive correlation -0.83 . The slaughter weight correlated average with dressing percentage and conformation score $(0.50$ and -0.52$)$. For other traits, the observed correlations are weak.

Positive correlation between slaughter weight and carcass conformation was found by Hickey et al.
(2007) in the Holstein sire breed group - correlation was 0.36 . In our study, the correlation between traits slaughter weight and conformation score is negative --0.52 . This can be explained by the method which is used by EUROP scale grading because we used the lowest value for the best carcass conformation score.

\section{Conclusions}

$\mathrm{AB}$ pure-bred bulls were slaughtered youngest at $519 \pm 16.6$ days of age, which was significantly different from HE pure-bred and HE crossbreed group bulls with the age of slaughter $584 \pm 7.3$ and $562 \pm 9.4$ days, respectively.

HE crossbreed group bulls showed the biggest weight before slaughter and slaughter weight - 557 $\pm 19.4 \mathrm{~kg}$ and $293 \pm 12.2 \mathrm{~kg}$, respectively. AB purebred group bulls showed the biggest daily weight gain from birth to slaughter $-952 \pm 24.7 \mathrm{~g}$, but the highest dressing percentage was gained from $\mathrm{AB}$ crossbreed group bulls, on average, $52.8 \pm 0.49 \%$.

Carcass conformation score in the study groups was from 3.2 to 3.5 points, but the best score was for $\mathrm{AB}$ pure-bred group of bulls $-3.2 \pm 0.08$ points. The highest fat score showed HE crossbreed group of bulls $-2.4 \pm 0.10$ points.

The obtained results prove that pure-bred and crossbreed bulls used in this research are suitable for fattening with grass in the conditions of Latvia. The best fattening and slaughter results showed $\mathrm{AB}$ purebred and $\mathrm{AB}$ crossbreed bulls. HE pure-bred bulls grew more slowly and they showed worse slaughter results as other group bulls. Therefore, for fattening with grass fodder more suitable are HE crossbreed bulls because they showed better growing and slaughter results than HE pure-bred bulls.

Among the traits of live weight before slaughter and daily weight gain from birth to slaughter, live weight before slaughter and slaughter weight, and daily weight gain from birth to slaughter and slaughter weight had a strong positive significant correlation. 


\section{References}

1. Alberti, P., Panea, B., Sanudo, C., Olleta, J.L., Ripoll, G., Ertberg, P., ... Williams, J.L. (2008). Live weight, body size and carcass characteristics of young bulls of fifteen European breeds. Livestock Science, 114, 19 - 30. DOI: 10.1016/j.livsci.2007.04.010.

2. Barton, L., Rehak, D., Teslik, V., Bures, D., \& Zahradkova, R. (2006). Effect of breed on growth performance and carcass composition of Aberdeen Angus, Charolais, Hereford and Simmental bulls. Czech Journal of Animal Science, 51(2), $47-53$.

3. Chambaz, A., Scheeder, M.R.L., Kreuzer, M., \& Dufey, P.A. (2003). Meat quality of Angus, Simmental, Charolais and Limousin steers compared at the same intramuscular fat content. Meat science, 63(4), 491 500. DOI: 10.1016/S0309-1740(02)00109-2.

4. Chassot, A. (2008). Mastleistung von Angus und Eringer Mastremonten (Fattening results of Angus and Eringer cattle). Agrar Forschung, 15(10), 492 - 497. (in German).

5. Chassot, A. (2015). Die Rindfleischproduktion und die Umwelt (The cattle meat production and environment). Agrar Forschung, 15(10), 479. (in German).

6. Dannenberger, D., Nuernberg, K., Nuernberg, G., \& Ender, K. (2006). Carcass - and meat quality of pasture vs concentrate fed German Simmental and German Holstein bulls. Archiv Tierzucht, 49(4), 315 328.

7. Hickey, J.M., Keane, M.G., Kenny, D.A., Cromie, A.R., \& Veerkamp, R.F. (2007). Genetic parameters for EUROP carcass traits within different groups of cattle in Ireland. Journal of Animal Science, 85(2), 314 321. DOI: $10.2527 /$ jas.2006-263.

8. Hollo, G., Nuernberg, K., Somogyi, T., Anton, I., \& Hollo, I. (2012). Comparison of fattening performance and slaughter value of local Hungarian cattle breeds to international breeds. Tierzucht, 55(1), $1-12$.

9. Huuskonen, A., Tuomisto, L., Joki-Tokola, E., \& Kauppinen, R. (2009). Animal performance and carcass characteristics of growing Hereford bulls under insulated, uninsulated and outdoor housing conditions in Northern Finland. Agricultural and Food Science, 18(1), 16 - 26.

10. Jukna, V., Jukna, Č., Prusevičius, V., Meškinyte-Kaušiliene, E., \& Pečiulaitiene, N. (2017). Meat quality of different beef cattle breeds fed high energy forage. Zemdirbyste-Agriculture, 104(3), 277 - 282. DOI: 10.13080/z-a.2017.104.035.

11. Lujāne, B., Ošmane, B., \& Jansons, I. (2013). Liellopu gal̦as ražošana (Production of cattle meat). Latvijas iedzīvotāju pārtikā lietojamās gal̦as raksturojums (pp. 105-156). Latvijas Lauksaimniecības Universitātes Biotehnologijas un veterinārmedicīnas zinātniskais institūts „Sigra”. (in Latvian).

12. Muizniece, I., \& Kairisa, D. (2016). Different beef breed cattle fattening results analysis. Research for rural development 2016: Annual 22st International scientific conference proceedings, 18 - 20 May 2016 (pp. 57 - 62). Jelgava, Latvia: Latvia University of Agriculture.

13. Pesonen, M., Honkavaar, M., \& Huuskonen, A. (2013). Production, carcass and meat quality traits of Hereford, Charolais and Hereford Charolais bulls offered grass silage-grain-based rations and slaughtered at high carcass weights. Acta Agriculturae Scandinavica, Section A-Animal Science, 63(1), 28 - 38. DOI: 10.1080/09064702.2013.777091.

14. Pesonen, M., Honkavaar, M., \& Huuskonen, A. (2012). Effect of breed on production, carcass traits and meat quality of Aberdeen Angus, Limousin and Aberdeen Angus x Limousin bulls offered a grass silagegrain-based diet. Agricultural and Food science, 21(4), 361 - 369.

15. Philips, C.J.C. (2010). Principles of cattle production. (2nd ed.) Cambridge, UK: CABI publications, Cabridge University Press. 